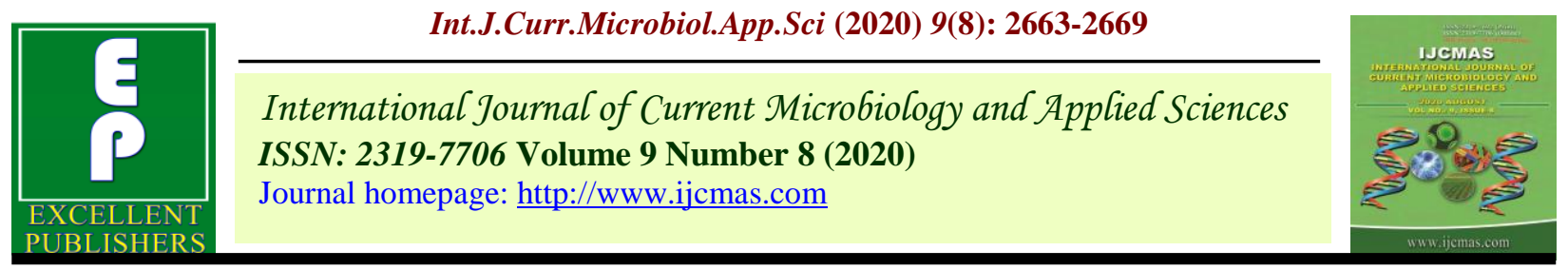

\title{
Performance of Soybean-Safflower Cropping System under BBF Land Configuration under Different Spacing and INM over Traditional Method
}

\author{
Pritam O. Bhutada*, S.B. Ghuge and C.B. Patil \\ All India co-ordinated Research Project on Safflower, V.N.M.K.V., Parbhani (M.S.), India \\ *Corresponding author
}

\begin{tabular}{|l|}
\hline Ke y w o r d s \\
$\begin{array}{l}\text { Soybean- Safflower } \\
\text { cropping system, } \\
\text { BBF method of } \\
\text { sowing }\end{array}$ \\
\hline Article Info \\
\hline $\begin{array}{l}\text { Accepted: } \\
\text { 22 July 2020 } \\
\text { Available Online: } \\
\text { 10 August 2020 }\end{array}$ \\
\hline
\end{tabular}

\section{Introduction}

In rainfed farming, conservation of moisture in soil has great importance to improve the crop productivity. Watershed based conservation practices are not suitable every field it can possible in heavy rainfall or low land areas. For field crop need to adopt the insitu based soil moisture conservation practices. The broad bed furrow based sowing of crop is an emerging practice in rainfed farming for not only increase in yield but also help for in-situ soil moisture conservation. It helps to conserve in-situ water and makes the moisture availability for the sown crops. There are different method of sowing crop for in-situ moisture conservation such as contour method of sowing conserves soil moisture but it affects traditional practices for carrying farm operations. Broad bed furrow method is a precision method for in-situ moisture conservation and it is technology which includes ploughing to improve effectiveness and efficiency of traditional drainage practices. Akbar (2007) found that there was about $36 \%$ water saving for wide beds and 
about $10 \%$ for narrow beds and grain yield increase of about $6 \%$ for wheat crop and $33 \%$ for maize crop. For dry land zone and to overcome water logging and improve soil structure on cropping soils in case of high rainfall zone BBF farming is become solution. The furrows act as pathways for drainage in excessive rain and conserve rainwater in dry spell (Astatke et al., 2002). In rainfed agriculture oilseed crops play important role in economics and sources of fats and oils, which are essential for human diet, comprising about $40 \%$ of the calories in the diet of the average person. India is amongst the largest producer and consumer of vegetable oils in the World. Oilseeds have been the backbone of agricultural economy of India since long. Indian vegetable oil economy is the fourth largest in the world next to USA, China and Brazil.

Oilseed crops play the second important role in the Indian agricultural economy next to food grains in terms of area and production. Safflower [Carthamus tinctorius] is another very important oilseed crop grown world over. In India, it occupies about $5.9 \mathrm{~m}$ ha with a production of $6.8 \mathrm{~m} \mathrm{t}$ with an average productivity of $1145 \mathrm{~kg}$ ha (Economic survey, 2012-2013). It is a major rabi oilseed crop in the country. Like soybean its productivity is also very low as compared to the global average. Safflower is also greatly affected by the poor nutrient management and soil moisture. The study was carried out to Performance of safflower under BBF land configuration under different spacing, INM over traditional method.

\section{Materials and Methods}

\section{A BBF marker cum seed drill}

It having mechanical seed metering device mainly consists of frame, seed and fertilizer box metering mechanism, ridgers for opening broad bed furrows, inverted T-type furrow openers and ground wheel or driving wheel. The overall length and width of this machine is $185 \mathrm{~cm}$ and $180 \mathrm{~cm}$, respectively. The spacing between furrow openers can be increased or decreased according to the need of farmer or type of crop grown. The ridgers were provided to the implement for marking broad bed furrows. The broad bed furrows are prepared at the same time of sowing which save the time and cost of the operation. The furrow openers are inverted T-type and made of $10 \mathrm{~mm}$ thick mild steel. There are two boxes provided on seed drill, one for seed and other for fertilizer. To control the seed and fertilizer application rate, fluted type metering device was provided in the seed cum fertilizer drill. The seed adjustment lever was provided to control the seed rate. The power is transmitted to seed and fertilizer metering mechanism from ground wheel having $38 \mathrm{~cm}$ diameter by chain and sprocket arrangement. The depth of sowing can also be adjusted with the help of ground wheel

\section{Sowing of soybean-safflower by using BBF}

A field experiment was carried out during 2018-19 at AICRP on safflower, Vasantrao Naik Marathwada Krishi Vidyapeeth, Parbhani. In Split factorial design with three replication and 12 treatment.

\section{Treatment details}

\section{Main plot: $\mathrm{BBF}(2)$}

M1: Soybean (Short duration Variety)Safflower (Zero tillage/relay sowing)

M2: Soybean (Normal duration Variety)Safflower (Relay sowing)

Sub-plot: Safflower: Plant geometry

G1: 3 rows/BBF (row to row is $60 \mathrm{~cm}$ and plant is $15 \mathrm{~cm}$ ) 
$\mathrm{G} 2$ : 4 rows $/ \mathrm{BBF}$ (row to row is $40 \mathrm{~cm}$ and plant to plant is $20 \mathrm{~cm}$ )

IPNM: Soybean: RDF (30:60:30 P through $\mathrm{SSP}+$ seed treatment with Rhizobium) Safflower:

\section{N1:No fertilizer}

$\mathrm{N} 2$ : $50 \%$ RDF (as DAP) + seed treatment with Azotobazter+ PSB

N3: RDF (as DAP) + seed treatment with Azotobacter+ PSB

\section{Check plot: $10 \mathrm{~m} \times 10 \mathrm{~m}$}

\section{Sowing of Soybean by using BBF}

For sowing of soybean by BBF method row to row spacing between crop rows on broad bed was kept $30 \mathrm{~cm}$ with five rows of soybean crop on BBF. Sowing soybean done in kharif 2018-19 on $12^{\text {th }}$ June 2018. Two genotype used JS-9305- as short duration \& MAUS-71 as normal duration. All recommended package of practice fallowed.

\section{Sowing of safflower by using BBF}

Safflower in BBF method, spacing between rows and the cropping pattern was changed over traditional method. Row to row spacing between crop rows on broad bed was kept 40 $\mathrm{cm}$ with 4 rows and $60 \mathrm{~cm}$ with 03 rows. The plant to plant spacing $(20 \mathrm{~cm})$ was kept same as in traditional method of sowing safflower crop. The average depth of placement of seed in BBF method was observed to be $5 \mathrm{~cm}$ sowing of safflower done on rabi 2018-19 on20th Sept.2018. (sowing pattern in BBF method Fig.1) and in traditional method sowing of safflower done with $45 \mathrm{~cm}$ row to row distance and $20 \mathrm{~cm}$ plant to plant distance with depth of sowing $3 \mathrm{~cm}$ (sowing pattern in traditional method is shown in Fig. 2).

The data regarding moisture content of soil in both methods with the yield of crop was collected during the research work. The data regarding soil moisture content in the both methods was collected at month wise since from sowing to harvesting of safflower crop. System equivalent safflower based yield and economics was calculated.

\section{Results and Discussion}

\section{Soil moisture}

For determining moisture content of soil three samples of soil were selected randomly at three different depths, i.e. $0-5 \mathrm{~cm}, 5-10 \mathrm{~cm}$ and $10-20 \mathrm{~cm}$ from both the experimental plot. The average soil moisture for $\mathrm{BBF}$ method was found to be $34.86 \%(\mathrm{db})$ and in traditional method was recorded to be 31.14 $\%$ (Table 1). Similar result observed by V. P. Khambalkar (2010). The mulching with ricebarn and organic manuring notably improved soil physio-chemical properties for supportive plant growth (Tekwa et al., 2010). It was observed that in BBF sowing method (11.95 $\%$ more) soil moisture conserved over traditional method. Lenssen et al., (2007) concluded that zero tillage had more available water at planting for safflower crop.

\section{Yield, economics of Soybean-safflower cropping sequence}

\section{Yield of soybean}

Soybean on BBF method of sowing recorded higher average yield i.e. (1437 kg/ha) over traditional method of sowing i.e. (1350 $\mathrm{kg} / \mathrm{ha})$.

\section{Yield of safflower and Safflower equivalent yield, system economics}

Application of nutrients has a vital role in early and vigorous plant growth especially under scarcity areas. Balanced application of fertilizers at the time of sowing led to higher plant growth. BBF with proper application 
fertilizer and seed treatment might have conserved soil moisture and improve growth of plant it seems to increase in the yield of safflower might be ascribed to cumulative effect of improvement in the growth as well as yield attributes and increased availability of the essential nutrients throughout the crop growth period. The results of present investigation are in lines with that of Girase et al., (1997. Yield of safflower observed higher in treatment 3 rows/BBF $x$ 100\% RDF + Azotobacter + PSB (1712 kg/ha) which was on par with 4 rows/BBF $\times 100 \%$ RDF + Azotobacter + PSB (1569 kg/ha) over treatment 3 rows/BBF $x$ no $\mathrm{RDF} \& 3$ rows/BBF x 50\% RDF + Azotobacter+ PSB and 4 rows/BBF $\mathrm{x}$ no $\mathrm{RDF} \& 4$ rows/BBF $\mathrm{x}$ $50 \% \mathrm{RDF}+$ Azotobacter+ PSB and check tradional method of sowing $(1490 \mathrm{~kg} / \mathrm{ha})$. Similar trend observed in case of biological yield (Table 2 \& 3). The moisture stress seriously affects on the grain amaranth than fertilizer stresses and yield of grain depends on the soil moisture status (Ejieji and Adeniran, 2010; Lenssen et al., 2007). The better yield from crop grown on ridges compared with those on flat land (Tisdall and Hodgson, 1990). As found that average yields of soybean \& safflower increased by $6 \%$ and $14 \%$ respectively over traditional method of sowing. The total productivity of the soybeansafflower cropping sequence expressed in terms of safflower equivalent yield indicated that it differed significantly due to BBF land configuration and nutrient management to both the crops during years of investigation. The safflower equivalent yield of the cropping system was significantly higher with the practice of broad bed furrows than the flat beds practices or traditional method of sowing. The higher equivalent yield ( $\mathrm{kg} / \mathrm{ha})$ might be attributed to proper utilization of nutrients due to its sustained availability which resulted in better crop growth and ultimately higher grain yield. Similar findings were also reported by Tomar et al., (1996), Prajapat et al., (2014) [25] and Wanil et al., (2011). From the result of study it is found that performance of Soybean-safflower cropping system under BBF land configuration is better over traditional practice and sowing of safflower 3 rows/BBF $\mathrm{x} 100 \% \mathrm{RDF}+$ Azotobacter + PSB fallowed by 4 rows $/ \mathrm{BBF} \times 100 \% \mathrm{RDF}+$ Azotobacter + PSB.

Table.1 Soil moisture in BBF and traditional method of safflower sowing season

\begin{tabular}{|l|c|c|}
\hline Month & $\begin{array}{c}\text { Soil moisture in BBF } \\
(\boldsymbol{\%})\end{array}$ & $\begin{array}{c}\text { Soil moisture in } \\
\text { Traditional (\%) }\end{array}$ \\
\hline October-19 & 50.5 & 45.2 \\
\hline November-19 & 41.22 & 40.15 \\
\hline December-19 & 35.75 & 31.11 \\
\hline Janevary-19 & 30.88 & 28.45 \\
\hline Februvary-19 & 30.2 & 25.33 \\
\hline March-19 & 28.75 & 24.5 \\
\hline April-19 & 26.75 & 23.25 \\
\hline $\begin{array}{l}\text { Average soil } \\
\text { misture (\%) }\end{array}$ & 34.86 & 31.14 \\
\hline
\end{tabular}


Table.2 Soybean, safflower yield, safflower equivalent yield and system economics of BBF method sowing

\begin{tabular}{|c|c|c|c|c|c|c|c|c|}
\hline \multirow{2}{*}{ Treatments } & \multicolumn{2}{|c|}{ Seed yield $(\mathrm{kg} / \mathrm{ha})$} & \multirow{2}{*}{$\begin{array}{l}\text { Biological } \\
\text { yield of } \\
\text { safflower } \\
\text { (kg/ha) }\end{array}$} & \multirow{2}{*}{$\begin{array}{c}\text { Safflower } \\
\text { equivalent } \\
\text { yield } \\
\text { (kg/ha) }\end{array}$} & \multicolumn{4}{|c|}{ System economics } \\
\hline & Soybean & Safflower & & & $\begin{array}{l}\text { Gross } \\
\text { Return } \\
\text { (Rs/ha) }\end{array}$ & $\begin{array}{c}\text { Cost of } \\
\text { Cultivation } \\
\text { (Rs/ha) }\end{array}$ & $\begin{array}{l}\text { Net } \\
\text { Return } \\
\text { (Rs/ha) }\end{array}$ & $\begin{array}{c}\text { B:C } \\
\text { Ratio }\end{array}$ \\
\hline \multicolumn{9}{|l|}{ Main plot (Kharif) } \\
\hline $\begin{array}{l}\text { Soybean - JS 9305 } \\
\text { (Short duration) }\end{array}$ & 1292 & 1745 & 8063 & 2337 & 93480 & 45350 & 48130 & 2.1 \\
\hline $\begin{array}{l}\text { Soybean - MAUS- } \\
71 \text { (Normal } \\
\text { duration) }\end{array}$ & 1581 & 1681 & 7530 & 2458 & 98320 & 45350 & 52970 & 2.2 \\
\hline S.Em \pm & & 44.7 & 71.3 & 22.1 & & & & \\
\hline C.D $(\bar{p} \leq 0.05)$ & & NS & 434 & NS & & & & \\
\hline \multicolumn{9}{|c|}{ Sub plot (Rabi) (Plant geometry $x$ IPNM) } \\
\hline $\begin{array}{l}3 \text { rows/BBF x No } \\
\text { Fertilizer }\end{array}$ & & 1013 & 4800 & 2016 & 80640 & 43900 & 36740 & 1.8 \\
\hline $\begin{array}{l}3 \text { rows } / \text { BBF x } 50 \% \\
\text { RDF }+ \\
\text { Azotobacter+ PSB }\end{array}$ & & 1268 & 6270 & 2303 & 92120 & 45400 & 46720 & 2.0 \\
\hline $\begin{array}{l}3 \mathrm{rows} / \mathrm{BBF} \mathrm{x} \\
100 \% \mathrm{RDF}+ \\
\text { Azotobacter + PSB }\end{array}$ & & 1630 & 7510 & 2742 & 109680 & 46900 & 62780 & 2.3 \\
\hline $\begin{array}{l}4 \text { rows/BBF x No } \\
\text { Fertilizer }\end{array}$ & & 1109 & 5413 & 2108 & 84320 & 43800 & 40520 & 1.9 \\
\hline $\begin{array}{l}4 \text { rows at } / \text { BBF x } \\
50 \% \text { RDF + } \\
\text { Azotobacter+ PSB }\end{array}$ & & 1299 & 5677 & 2362 & 94480 & 45300 & 49180 & 2.1 \\
\hline $\begin{array}{l}4 \mathrm{rows} / \mathrm{BBF} \mathrm{x} \\
100 \% \mathrm{RDF}+ \\
\text { Azotobacter/ + PSB }\end{array}$ & & 1713 & 7797 & 2854 & 114160 & 46800 & 67360 & 2.4 \\
\hline S.Em \pm & & 54.2 & 342 & 64.5 & & & & \\
\hline$C . D(p \leq 0.05)$ & & 160 & 1010 & 190 & & & & \\
\hline C.V (\%) & & 9 & 13 & 7 & & & & \\
\hline Interaction & & NS & NS & NS & & & & \\
\hline
\end{tabular}

Table.3 Soybean, safflower yield on traditional method of sowing

\begin{tabular}{|l|r|r|r|r|r|}
\hline $\begin{array}{c}\text { Check plot } \\
\mathbf{1 0 x 1 0 m 2}\end{array}$ & $\begin{array}{c}\text { seed yield } \\
\text { (kg/ha) }\end{array}$ & GMR Rs/ha & NMR Rs/ha & $\begin{array}{c}\text { cost of } \\
\text { cultivation } \\
\text { (Rs./ha) }\end{array}$ & B:C ratio \\
\hline Soybean(ND) & 1350 & 39825 & 19125 & 20700 & 1.92 \\
\hline Safflower & 1490 & 59600 & 33450 & 26150 & 2.28 \\
\hline
\end{tabular}


Fig.1 BBF method

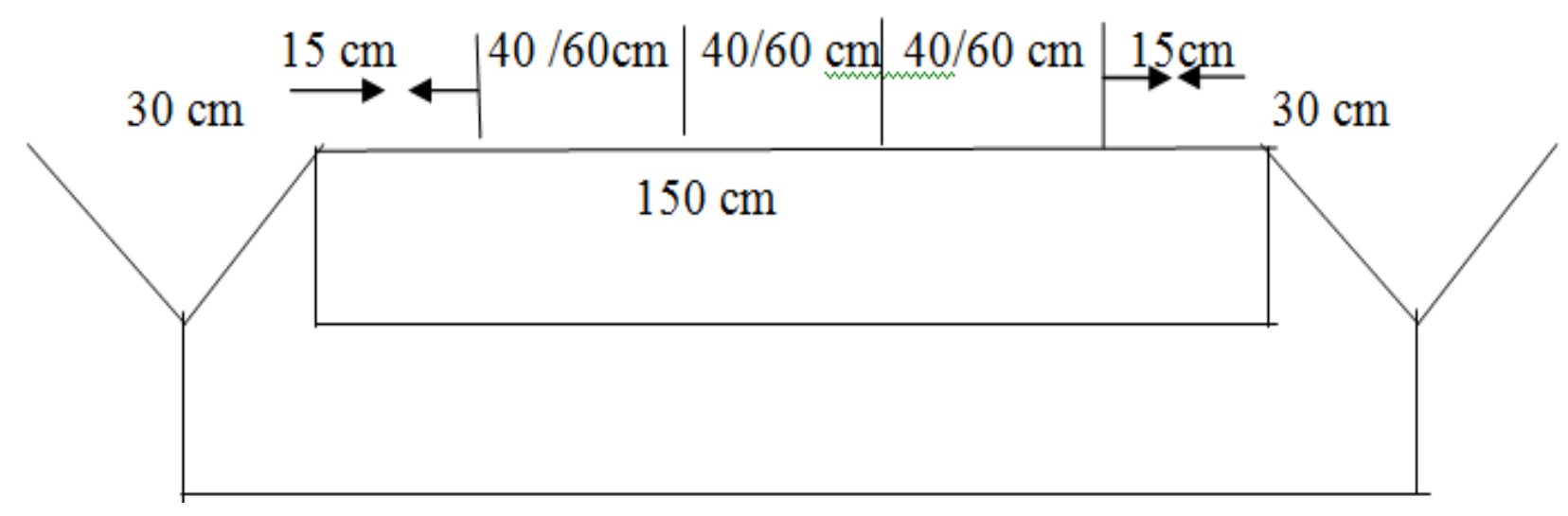

Fig.2 Traditional method

\begin{tabular}{l|l|l|l|l} 
& $45 \mathrm{~cm}$ & $45 \mathrm{~cm}$ & $45 \mathrm{~cm}$ & \\
& & & & \\
\hline
\end{tabular}

\section{References}

Akbar G, Hamilton G, Hussain Z, Yasin M (2007) Problems and potentials of permanent raised bed cropping systems in Pakistan. Pakistan Journal of Water Resources, 11(1):11-21

Astatke A, Jabbar M, Mohamed MA, Erkossa $T$ (2002) Technical and economical performance of animal drawn implements for minimum tillageexperience on vertisols in ethopia. Experimental Agriculture, 38(2): 185196

Ejieji CJ, Adeniran KA (2010) Effects of water and fertilizer stress on the yield, fresh and dry matter production of grain Amaranth (Amaranthus cruentus). Aust J Ag Eng 1(1):18-24

Girase PD, Kamble LB, Deolankar AB. Response of safflower to application of fertilizer under rainfed condition.
Journal of Maharashtra Agricultural Universities. 1997; 1:148-149.

Gupta CP, Undadi A (1994) Development of two wheel tractor operated seed-cumfertilizer drill. AMA 25(1): 25-28

Lenssen AW, GD Johnson, GR Carlson (2007) Cropping sequence and tillage system influences annual crop production and water use in semiarid Montana, USA. Field Crops Research, 100: $32-43$

Prajapat K, Vyas AK, Shiva Dhar. Productivity, profitability and land-use efficiency of soybean based cropping system under different nutrient management practices. Indian Journal of Agronomy. 2014; 59(2):229- 234.

Singh P, Alagarswamy G, Pathak P, Wani SP, Hoogenboom G, Virmani SM. Soybeanchickpea rotation on Vertic Inceptisols I. Effect of soil depth and landform on light interception, water balance and 
crop yields. Field Crops Res. 1999b; 63(3):211-224. 24. Tomar RK, Namdeo SKN, Raghu JS. Productivity and economics of double cropping with pulses and oilseeds against the base crop wheat (Triticum aestivum) Indian J Agron. 1996; 41(2): 205-208.

Tisdall JM, AS Hodgson (1990) Ridge tillage in Australia: a review. Soil \& Tillage Research, 18: 127-144
Khambalkar, V. P., S. M. Nage, C. M. Rathod, A. V. Gajakos, Shilpa Dahatonde (2010). Mechanical sowing of safflower on broad bed furrow. Aust J Ag Eng 1(5):184-187.

Wani AG, Patil VS, Todmal SM. Efficient alternative cropping Project Directorate for Farming Systems Research, Modipuram, Meerut, India, 2011, 339p.

\section{How to cite this article:}

Pritam O. Bhutada, S.B. Ghuge and Patil, C.B. 2020. Performance of Soybean-Safflower Cropping System under BBF Land Configuration under Different Spacing and INM over Traditional Method. Int.J.Curr.Microbiol.App.Sci. 9(08): 2663-2669.

doi: https://doi.org/10.20546/ijcmas.2020.908.304 